\title{
TRIPS FLEXIBILITIES AND INDIA'S PLANT VARIETY PROTECTION REGIME: THE WAY FORWARD
}

\author{
ROHIT MOONKA, \\ Institute of Law, Nirma University (Ahmedabad, India) \\ SILKY MUKHERJEE, \\ Institute of Law, Nirma University (Ahmedabad, India)
}

DOI: 10.21684/2412-2343-2017-5-1-117-139

Article 27.3(b) of the TRIPS Agreement provides that members shall provide for protection of plant varieties either by patents or by an effective sui generis protection or both. While WTO member countries can choose from among intellectual property strategies to protect plant varieties, they may not choose to exclude plant varieties from IP rights protection without facing trade sanctions from the WTO dispute resolution body. The open-ended language of the article creates a flexible standard of protection sympathetic to developing nations' socio-economic priorities, provided that the effectiveness requirement is satisfied. This flexibility presents a range of possibilities from systems like the plant patent regime of the United States or specific variety protection systems of the European Union to the possibility of customized plant protection regimes suited to the needs of developing nations.

India, while complying with the requirements of the TRIPS Agreement for the protection of plant varieties, enacted the Protection of Plant Varieties and Farmers' Rights Act. The fundamental ideology of the PPVFR Act is to address India's concerns about protecting the rights of small and marginal farming communities, while at the same time promoting plant breeding by vesting a dequate IP rights protection which will boost further research and innovation in this field.

This paper argues that as it is necessary to recognize and protect the rights of farmers in respect of their contribution made at any time in conserving, improving and making available plant genetic resources for the development of new plant varieties, the PPVFR Act has maintained a balance between breeders' rights and farmers' rights. The PPVFR Act protects farmers'rights to save, use, exchange and share all farm produce, including 
seeds that fall within the purview of the Act, and it provides protection of indigenous knowledge against unwary monetization.

Keywords: plant variety protection; TRIPS; India; farmers' rights.

Recommended citation: Rohit Moonka \& Silky Mukherjee, TRIPS Flexibilities and India's Plant Variety Protection Regime: The Way Forward, 5(1) BRICS Law Journal 117139 (2018).

\section{Introduction}

For decades, Indian policy on plant varieties and seeds was based on the principle of the common heritage of mankind. Post-independence, Indian governments adopted a system wherein plant breeding activities were largely confined to the public sector post-independence to address national food security issues.' This policy to a large extent succeeded when at the end of the 1970s India achieved the milestone of transitioning from being an importer of foodgrains to achieving selfsufficiency in food. ${ }^{2}$ India did not want monopolies to develop in crucial areas like agriculture and hence the government produced seeds through its own agencies and distributed them cheaply to the public. India's move towards promoting farming trade was partly prompted by the entry of overseas seed corporations into the Indian market in the early 1980s, which gave rise to demands for Intellectual Property (IP) rights protection. ${ }^{3}$ Further, India, being a World Trade Organization (WTO) member was required to adhere to the standards set out in the Agreement on Trade-Related Aspects of Intellectual Property Rights (TRIPS) for the protection of plant varieties. ${ }^{4}$ From there, India had to shift its age-old principle of common heritage and was obliged to provide protection to plant varieties either through patent or a sui generis system, or a combination of both.

The Protection of Plant Varieties and Farmers' Rights (PPVFR) Act, $2001^{5}$ is primarily considered as an upshot of the pressures from India's membership in

N.S. Gopalakrishnan, An "Effective" Sui Generis Law to Protect Plant Varieties and Farmers' Rights in India, 4(1) Journal of World Intellectual Property 157, 158 (2001).

2 India: Economic Development: Evolution of Policy (September 1995) (Feb. 10, 2018), available at http:// www.country-data.com/cgi-bin/query/r-6093.html.

3 Id.

4 TRIPS Agreement, Art. 27.3(b) (Feb. 10, 2018), available at https://www.wto.org/english/docs_e/ legal_e/27-trips.pdf.

5 The Protection of Plant Varieties and Farmers' Rights Act, No. 53 of 2001, India Code (2001), Vol. 64, at 1 (Feb. 10, 2018), available at http://www.plantauthority.gov.in/pdf/PPV\&FRAct2001.pdf (hereinafter PPVFRA). 
the WTO by the developed countries, as well as the entry of overseas corporations into the Indian market. Exercising the flexibility given under the TRIPS Agreement with regard to the defence for Plant Varieties Protection (PVP), India chose a sui generis structure to protect plant varieties with a view to balancing the interests of both breeders' rights and farmers' rights without succumbing to the pressures of developed countries to became a member of the International Union for the Protection of New Varieties of Plants (UPOV) Convention (1961) or to enact a law for plant varieties protection based on the UPOV model. Since India is also a member of the International Treaty on Plant Genetic Resources for Food and Agriculture (ITPGRFA), which has got substantial provisions on farmers' rights and contains a chapter on it, makes it obligatory on the member state to provide for its safeguard through the national legislative process.

Below, the unique features of the PPVFR Act are discussed in order to understand how India has tried to maintain a balance between two very important rights through one piece of legislation, i.e. the PPVFR Act, so as to fulfil the effectiveness test under Art. 27.3(b) of the TRIPS Agreement.

\section{Indian Initiative for the Protection of Plant Varieties and Farmers' Rights}

The PPVFR Act differs significantly from the UPOV model to the extent it emphasizes the rights of farmers

in respect of their contribution made at any time in conserving, improving, and making available plant genetic resources for the development of new plant varieties. ${ }^{6}$

The PPVFR Act protects farmers' rights to save, use, exchange, and share all farm produce, including seeds that fall within the purview of the Act and it provides protections of indigenous knowledge against unwary monetization. ' Having said that, this Act also does not disregard the breeders' rights and to a large extent provide the analogous criteria for protection of new varieties of plant as provided under the UPOV 1991 Act, which has been the subject matter of considerable debate.

The fundamental philosophy of the PPVFR Act is to address India's concerns about protecting the rights of small and marginal farming communities, while at the same time promoting plant breeding by vesting adequate IP rights protection which will boost further research and innovation in this sphere. It is evident from the very objective of this Act that it has been enacted to

\footnotetext{
6 PPVFRA, Preamble.

Supra note 5.
} 
provide for the establishment of an effective system for protection of plant varieties, the rights of farmers and plant breeders and to encourage the development of new varieties of plants ${ }^{8} \ldots$ [as] it is considered necessary to recognize and safeguard the rights of the farmers in respect of their contributions made since time immemorial in conserving, improving and making available plant genetic resources for the development of new plant varieties.

Further, to augment agricultural development in the country, it was necessary to protect plant breeders' rights so as to stimulate investment for research and development, both in the public and in the private sector, for the development of new plant varieties, as such protection will expedite the growth of the seed industry in the country which in turn will ensure the availability of high quality seeds and planting material to the farming communities. ${ }^{9}$

The Preamble further elaborates that to give effect to the aforesaid objectives it is necessary to undertake processes for the protection of the rights of farmers and plant breeders, and as India has ratified the TRIPS Agreement it should inter alia make facility for giving effect to TRIPS provisions in this regard, i.e. subpara. (b) of para. 3 of Art. 27 in Part II relating to protection of plant varieties. The PPVFR Act provides for plant varieties in three protected categories:

(a) New Varieties,

(b) Extant Varieties, which refer to existing varieties revealed for the first time, and

(c) Farmers' Varieties, based on public property concepts. ${ }^{10}$

The salient features of the PPVFR Act will be examined in order to understand the layers of protection it provides both to breeders' rights and to farmers' rights.

\subsection{New Variety}

Under the PPVFR Act, a variety is eligible for protection provided it is novel, distinct, uniform and stable." However, it is contended that while making these criteria for the protection of a new variety, the requirement for novelty is quite similar to the UPOV 1991 Act which also contains the same criteria for the protection of a new plant variety. Further varieties not "sold or otherwise disposed of" in India more than a year prior to filing, or outside India for more than four or six years, depending on the type of plant, can pass the novelty test under the PPVFR Act. ${ }^{12}$

\footnotetext{
8 PPVFRA, Preamble.

9 ld.

10 Id. at Sec. 15(2).

11 Id. at Sec. 15.

12 Id. at Sec. 15(3)(a).
} 
In this situation, becoming "a matter of common knowledge" on the date of application, by any methods other than by sale or disposal, does not affect the novelty of the proposed new plant variety for protection under the PPVFR Act. ${ }^{13}$ On the line of the novelty criteria, the descriptions of distinctiveness, uniformity and stability under the PPVFR Act also follow the UPOV 1991 Act definitions. ${ }^{14}$ Due to this, it has been contended that despite that India is not a member of UPOV Convention, but due to the acute pressure from developed countries, it has adopted some of the key provisions of the UPOV 1991 Act and incorporated them in the PPVFR Act, which is something that is not beneficial for its national interests.

Under the PPVFR Act, any breeder, farmer or community of farmers may apply for registration of a new variety. ${ }^{15}$ The difference with the PPVFR Act lies in the registration system, which enables protection for new varieties while at the same time recognizing the role of indigenous and traditional farmers. For instance, every application for registration must include a denomination of the variety and explain (1) the geographical source of the material and (2) all information regarding the contribution of the farmer, community or organization in the growth of the variety.$^{16}$ Further, the application for registration under the PPVFR Act must state that all genetic or parental material used to develop the variety has been legally acquired. $^{17}$

Furthermore, Sec. 40 of the PPVFR Act requires the breeder to disclose information "regarding the use of genetic material conserved by any tribal or rural families in the breeding or development of such new variety." ${ }^{18}$ The information in the application is intended to simplify benefit sharing, introduced to protect farmers' rights. Contrasted with the UPOV 1991 Act, the PPVFR Act contains a set of public-interest exceptions to the registration of a new variety as a safeguard to take care of larger national interests. For example, a new variety will not be registrable if it is likely to misinform the public, hurt the religious sentiments of any class or section of Indians or cause confusion regarding the variety's identity, or is not different from every denomination which designates a variety of the same botanical species or of a closely related species registered under the Act. ${ }^{19}$

While the farmers' role is secured by the benefit-sharing arrangement, the breeders' rights are also taken care of by using a mix of exclusive rights and severe

\footnotetext{
13 PPVFRA, Sec. 15(3) proviso.

14 Id. at Sec. 15.

15 Id. at Sec. 16(1)(d).

16 Id. at Sec. 18(1)(e).

17 Id. at Sec. 18(I)(h).

18 Id. at Sec. 40.

19 Id. at Sec. 15(4).
} 
penalties for infringement of the exclusive rights of the breeders. The PPVFR Act provides the breeders exclusive commercial rights over the variety, once registered, including licensing, production, sales, marketing, distribution and importing and exporting. ${ }^{20}$ The statute tries to deter infringement by providing stringent penalties, at rupees 50,000 (ca. euros 640.00) or imprisonment for a minimum of three months, which is provided to safeguard the breeders' interests and motivation to innovate without the fear of infringement.

\subsection{Extant Variety}

This is an exceptional provision under the PPVFR Act, as the introduction of extant variety and farmers' variety was meant to create a balance between breeders' rights and the rights of farmers and to give them a level playing field. The extant variety category itself was introduced to safeguard traditional knowledge and indigenous rights. ${ }^{21}$ The extant variety register serves as a gathering of matters known and existing in the public domain. Under the PPVFR Act, an extant variety encompasses a farmers' variety, or a variety about which there is common knowledge, or a variety in the public domain, as well as any variety included under Sec. 5 of the Seeds Act. ${ }^{22}$

Considering that the extant variety register is a record of materials available in the public domain, the registration requirements are not very thorough. To register an extant variety, it need not be novel, although the requirements of distinctiveness, uniformity and stability are regulated by administrative notifications issued (which are made by the Protection of Plant Variety and Farmers' Rights Authority of India (hereinafter Plant Authority)) from time to time. ${ }^{23}$ By making farmers' variety a subcategory of the extant variety, the PPVFR Act reassures farmers that to register varieties they have cultivated for ages will ensure that they are not misappropriated. The most significant benefit is that registration or compilation of extant varieties creates an advance standard for distinctness for registering "new" varieties under the PPVFR Act. In that sense, it prevents protection of infinitesimal innovations by plant breeders. To that extent, the PPVFR Act deviates from the UPOV approach by creating a more careful instrument to maintain the exclusivity of the protected varieties.

However, the deficiency is that the condition for registration of extant varieties is not noticeably provided in the PPVFR Act. What is provided under the PPVFR Act is that

\footnotetext{
20 PPVFRA, Sec. 28.

21 Id. at Sec. 14(b).

22 Id. at Sec. 2(j).

${ }^{23}$ Id. at Sec. 15(2).
} 
Notwithstanding anything contained in sub-section (1), an extant variety shall be registered if it conforms to distinctiveness, uniformity and stability as specified under the regulations $\mathrm{s}^{24}$

by the Plant Authority. Hence, it is obvious from this provision that the novelty criterion is not required for registering an extant variety.

These regulations were set down in "The Gazette of India" notification issued by the Indian government on 7 December 2006. ${ }^{25}$ According to this "Gazette" notification, the Plant Authority established an Extant Variety Registration Committee, which was given the assignment of making recommendations for the registration of extant variety of notified variety as provided under the Seeds Act 1966. ${ }^{26}$ This "Gazette" notification also states that the distinctiveness, uniformity and stability (DUS) criteria for registration of extant varieties will vary from species to species and they shall be notified by the Plant Authority in "The Gazette of India" from time to time. ${ }^{27}$ Since the registration of the extant variety does not necessitate the fulfilment of the novelty criteria, the registration of such varieties is not the same as those for the newly developed varieties or new varieties.

Under the PPVFR Act, an extant variety may be registered by a breeder, farmer, community of farmers, a university or a public sector. ${ }^{28}$ Although a breeder can also register an extant variety, the breeder is not entitled to exclusive rights over the extant variety. ${ }^{29}$ Section 28 of the PPVFR Act provides that the government, as the owner of the extant varieties, enjoys the rights to determine their production, sale, marketability, distribution, importation or exportation. ${ }^{30}$

The objective of having such a unique provision for extant varieties is to protect biodiversity by empowering the administration to bargain with such entities that require biodiversity materials for creating agro-biotechnology innovations. Nevertheless, Sec. 24 of the PPVFR Act creates the right to exploit an extant variety, over specific applicants, for a period of up to 15 years from the date of publication. ${ }^{31}$ In doing this, it prevents any private attainment of materials in the public domain. Since any person can make an application for registration of an extant variety under Sec. 16,

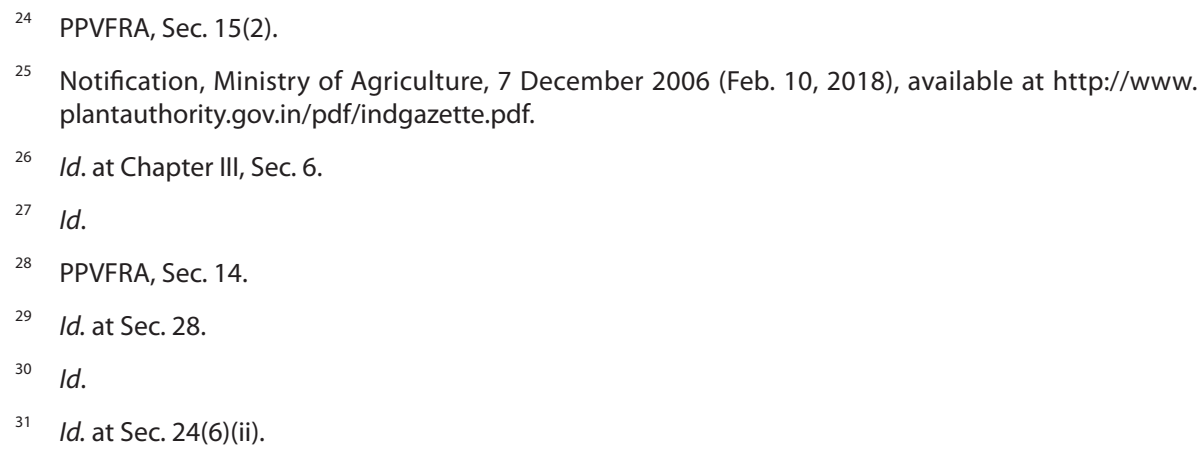


it permits the government to confer rights on the applicant for using the variety for a definite period. However, the difficulty with the extant registration is a twin problem. First, by imposing a term of protection for extant varieties it creates the impression that matters in the civic domain are not available in perpetuity. Secondly, allowing any third party to register an extant variety could apparently put some species in the public domain that are unregistered. Plants that are not commercially operational or are being used may never be registered, which will make the registry incomplete. In any case, it seems difficult to imagine that this mechanism would result in registration of all plants which are available in the public domain.

\subsection{Farmers' Variety}

One of most significant provisions of the PPVFR Act is in regard to the farmers' varieties. While doing so, it defines farmers from a public rights perspective as those who "cultivate crops by cultivating the land," and those who oversee farming directly or indirectly through other people, or anyone who

conserves and preserves, severally or jointly, with any other person through selection and identification of their useful properties. ${ }^{32}$

Under the PPVFR Act, a farmers' variety is one

which has been traditionally cultivated and evolved by the farmers in their fields, or is a wild relative or land race of a variety about which the farmers possess the common knowledge. ${ }^{33}$

The emphasis on common acceptance strengthens community rights, a notion which is completely ignored by the UPOV Convention. As far as determination of novelty and distinctiveness for registering a new variety is concerned, a variety becomes a matter of common knowledge only if it is protected or registered in any convention country. ${ }^{34}$ Other forms of common knowledge may not overthrow novelty or distinctiveness. For other purposes, the term "common knowledge" has been left largely undefined. Remarkably, even though the definitions of novelty and distinctiveness under the PPVFR Act follow the UPOV 1991 Act, the overall protection regime envisaged under the Act lessens some of the concerns. The manner of providing protection of a farmers'variety echoes a deep sense of consideration for the farmers and traditional community rights by including provisions for benefit-sharing, community compensation, immunity from prosecution for innocent infringement and

\footnotetext{
32 PPVFRA, Sec. 2(k).

33 Id. at Sec. 2(1).

34 Id. at Sec. 15(3)(a) proviso.
} 
the creation of a Gene Fund to accumulate breeders' annual fees..$^{35}$ Each of the rights provided in this regard not only signifies a departure from the UPOV Convention but also exhibits the rights contoured to suit distinctive national conditions, which is a point worth noting for other developing countries that are in the process of formulating their plant varieties laws in compliance with the TRIPS Agreement.

However, many critics point out that discretely categorizing a farmers' variety creates economic inadequacy in prosecuting claims for registering because farmers may be breeders, and vice versa. Though a farmer can be a breeder qualifying to register a new variety, a community of farmers that creates a new variety, for example, will not qualify for registration of the breeders' variety. The most important aspect of a farmers' variety is not to mollify farmers, but to create community property rights, different to that of the breeders' variety. The critics may be correct, however, when considering that farmers'variety is a subset of extant variety. While the extant variety encompasses everything in the public domain, farmers' variety is limited to materials traditionally cultivated by farmers or over which farmers own common knowledge. On the contrary, the breeders' variety is based on the developed countries notion of IP rights. However, creating two different systems of registrations has resulted in operative issues as the number of farmer's varieties which are registered are very fewer in number than new varieties and extant varieties.

Table 1: Year-Wise Trends of Filing of Application for Farmers' Varieties ${ }^{36}$

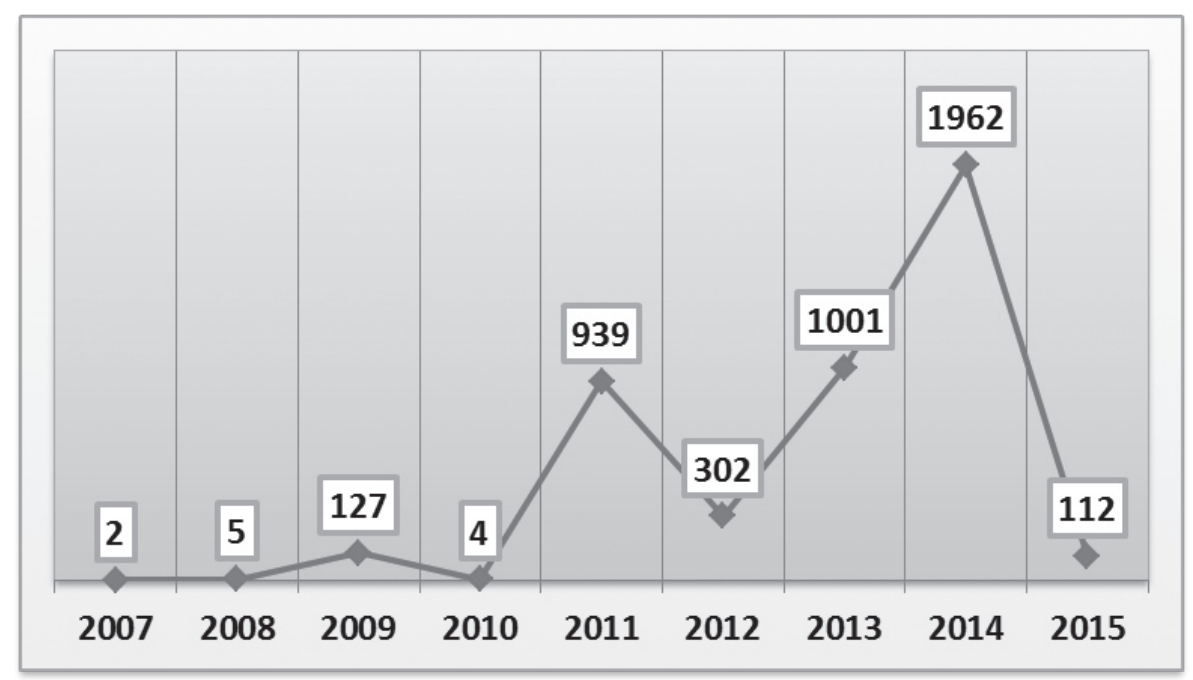

35 PPVFRA, Secs. 39-46.

36 Available at http://www.plantauthority.gov.in. 
With regard to the filing of applications for the registration of farmers' varieties, which commenced in 2007, the trend appears to be inconsistent. For the first three years it was an ascending trend with a sudden increase in filings of 127 applications during 2009. However, the trend in 2010 was far from favourable, with only four applications filed. On the contrary, during 2011 there was an unexpected rise in the filing of applications, namely 939, while in 2012 there was an abrupt drop with the filing of only 302 applications. Furthermore, during 2013 there was a record number of 1,001 applications received and the same tendency continued with 1,962 applications filed in 2014 and 112 applications by 21 January 2015 (the last date data were available), which was relatively an encouraging number, given the year was still so young.

Despite that PPVFR Act allows for the registration of a variety through two possible options, some critics have argued that the NDUS (i.e. novelty, distinctiveness, uniformity and stability) and DUS criteria (in case of extant variety) used for commercial breeders may not be suitable for farmer's variety, because these criteria are more suited for modern scientific methods of breeding and laboratory-based research, which the majority of survival farmers in a country such as India do not undertake. ${ }^{37}$ Moreover, since registration of a new variety is the only way to get protection under the PPVFR Act for farmers, many varieties developed by farmers will not enjoy any protection. ${ }^{38}$

It has been argued by many critics that the standards for registration in the PPVFR Act were taken from the UPOV 1991 Act, which was designed by developed countries that dominate the commercial breeders for the protection of plant varieties developed by commercial breeders who have the competence to a undertake modern and systematic research. ${ }^{39}$ In other words, the registration criterion, for registering farmer's varieties, in the PPVFR Act was not made to suit the hands-on situation that surrounds most of the farmers in India.

Although all stakeholders', i.e. commercial breeders, public research institutions and farmers can register their varieties, in practice only commercial plant breeders and public research institutions will be able to register their varieties, as they have the ability to undertake modern scientific breeding to fulfil the NDUS criteria or DUS criteria in the case of the registration of an extant variety.

Farmers in India, unlike the commercial plant breeders, follow conventional and not modern breeding processes or laboratory-based research. Hence, varieties developed by farmers may not be able to fulfil the NDUS criteria or DUS criteria in the event the farmers wish to register their varieties as extant varieties. As a result, very few farmers' varieties will benefit from the registration system provided in the PPVFR Act. ${ }^{40}$

37 Gopalakrishnan 2001, at 165.

38 Id.

39 Philippe Cullet, Intellectual Property Protection and Sustainable Development 277 (New Delhi: LexisNexis, Butterworths, 2005).

40 Id. 


\section{Other Prominent Features}

The most significant features of the PPVFR Act lie in areas where it deviates from the UPOV 1991 Act. As discussed below, these departures are the major pillars upon which rest attempts towards increasing the effectiveness of the PPVFR Act, addressing other worries particularly those of indigenous farmers and traditional communities.

\subsection{Right to Re-Sow}

One of the most extraordinary distinctions of the PPVFR Act is exhibited by its allowing the traditional and indigenous farmers to retain their age-old right to save and reuse seeds from their harvests. ${ }^{41}$ Under the PPVFR Act, a farmer is permitted to "save, use, sow, re-sow, exchange, share or even sell his produce," including nonbranded seed, even if it is a protected variety. ${ }^{42}$ This provision is a total departure from the UPOV 1991 Act which totally restricts this right of farmers. With a view to enabling the use of the right by farmers, Sec. 18 of the PPVFR Act further specifies that every application for a new variety be submitted along with an affidavit that the protected variety does not comprise any gene or gene succession involving terminator technology ${ }^{43}$ However, the only restriction to re-saving is that the farmer cannot use the breeder's brand name while reselling his harvest to anybody else. ${ }^{44}$ This condition safeguards the interests of the breeders so that the breeders maintain their commercial interests intact.

Nonetheless, it is submitted that while the objective of having these provisions is indeed commendable, the poorly drafted language of the section may lead to abuse of the provision. For example, extant varieties or farmers' varieties, which can be re-sowed, can be branded to prevent reuse by farmers. Considering the high level of illiteracy in India amongst the farmers, whether a farmer will be able to distinguish between new varieties and extant varieties is not very clear.

${ }^{41}$ Suman Sahai, India's Plant Variety Protection and Farmers' Rights Act, Bridges Comment (Feb. 10, 2018), available at http://iprsonline.org/ictsd/docs/SahaiBridgesYear5N8Oct2001.pdf.

42 PPVFRA, Sec. 39(1)(iv):"(iv) a farmer shall be deemed to be entitled to save, use, sow, re-sow, exchange, share or sell his farm produce including seed of a variety protected under this Act in the same manner as he was entitled before the coming into force of this Act: Provided that the farmer shall not be entitled to sell branded seed of a variety protected under this Act.

Explanation: For the purposes of clause (iv), 'branded seed' means any seed put in a package or any other container and labeled in a manner indicating that such seed is of a variety protected under this Act."

43 Id. at Sec. 18(1)(c): "Every application for registration under section 14 shall be accompanied by an affidavit sworn by the applicant that such variety does not contain any gene or gene sequence involving terminator technology."

44 Id. at Sec. 39(1)(iv). 
Termed "brown-bagging" by Western countries, farmers' traditional right to reuse protected varieties for re-sowing has been a touchy subject and one not given due recognition by developed countries that have adopted the UPOV Convention for providing protection for plant varieties. The UPOV 1991 Act does not recognize the right to reuse protected seeds, as discussed in the previous section. Breeders claim that the reusing of protected varieties by farmers takes away a part of their rightful compensation for the second generation seeds which they are not ready to part with. The breeders and the seed companies oppose the right to re-sow on the grounds that it is contrary to the principles of an effective IP rights system and would be an infringement of their rights and therefore should not be allowed. However, contrary to this notion, India has incorporated the provision whereby farmers' rights have been duly recognized and protected, which is something that has not gone down well with the developed countries that have interests in Indian markets.

Farmers, on the other hand, consider re-sowing as their intrinsic right. Many nongovernmental organizations (NGOs) such as Gene Campaign emphasize that the right to re-sow is significant for farmers to maintain their livelihoods and for a nation to remain self-sufficient. ${ }^{45}$ For example, farmers account for 87 percent of Indian seed production. ${ }^{46}$ Denying the right to re-sow would result in private corporations replacing farmers as the country's major seed producers. In countries like India where the farming population is significant, it is important to make welfare exceptions to keep the national interest ahead of commercial interests.

By introducing the right to save, use, sow, re-sow, exchange, share or sell his farm crops, the PPVFR Act eliminates the most crippling impediment to introducing formal plant variety protection in other developing nations without succumbing to the largely objectionable provisions in this regard of the UPOV 1991 Act by most of the developing countries. This exemption signifies a balance between fully allowing re-sowing (subject to not selling as branded varieties), on the one hand, and the UPOV arrangement tending towards preventing brown-bagging in total, on the other.

\subsection{Protecting Biodiversity}

The PPVFR Act puts weight on conventional and traditional farming practices to protect biodiversity. Traditional farmers are encouraged under the Act to conserve and improve inherited land resources, and for doing that they will be recognized and rewarded from the Gene Fund. ${ }^{47}$ The PPVFR Act has established a fund for this purpose called "Gene Fund" to reward farmers whose existing variety or material

45 Suman Sahai, India's Plant Variety Protection and Farmers' Rights Act, 2001, 84(3) Current Science 407, 409 (2003) (Feb. 10, 2018), also available at http://www.iisc.ernet.in/currsci/feb102003/407.pdf.

46 Id.

47 PPVFRA, Sec. 39(1)(iii): "[A] farmer who is engaged in the conservation of genetic resources of land races and wild relatives of economic plants and their improvement through selection and preservation shall be entitled in the prescribed manner for recognition and reward from the Gene Fund." 
is used as a source to create a new variety. ${ }^{48}$ This Gene Fund under the PPVFR Act is a common fund fashioned by the central government for the assistance and recognition of the farmers. ${ }^{49}$ Funds collected as royalties, funds collected towards benefit-sharing and other funds collected under that become due to farmers will be placed into the Gene Fund. ${ }^{50}$ The central government will use the funds towards

expenses for supporting the conservation and sustainable use of genetic resources including in-situ and ex-situ collections and for strengthening the capability of the village Panchayats for carrying out such projects. ${ }^{51}$

Moreover, if a farmer breeds a new variety, it would be subject to the same levels of protection and obligations, like benefit-sharing or community rights. ${ }^{52}$ If a breeder derives an essentially derived variety from a farmers' variety, then the breeder of the protected variety needs the authorization of the farmer or the community to commercialize the essentially derived variety. ${ }^{53}$ The underlying assumption is that any efforts that result in benefit-sharing should be used to encourage genetic diversity. ${ }^{54}$

48 PPVFRA, Sec. 39(1)(iii).

49 Id. at Sec. 45:"(1) The Central Government shall constitute a Fund to be called the National Gene Fund and there shall be credited thereto -

(a) the benefit sharing received in the prescribed manner from the breeder of a variety or an essentially derived variety registered under this Act, or propagating material of such variety or essentially derived variety, as the case may be;

(b) the annual fee payable to the Authority by way of royalty under sub-section (1) of section 35 ;

(c) the compensation deposited in the Gene Fund under sub-section (4) of section 41;

(d) the contribution from any national and international organization and other sources.

(2) The Gene Fund shall, in the prescribed manner, be applied for meeting -

(a) any amount to be paid by way of benefit sharing under sub-section (5) of section 26;

(b) the compensation payable under sub-section (3) of section 41;

(c) the expenditure for supporting the conservation and sustainable use of genetic resources including in-situ and ex-situ collections and for strengthening the capability of the Panchayat in carrying out such conservation and sustainable use;

(d) the expenditure of the scheme relating to benefit sharing framed under section 46."

$50 \quad I d$.

51 Id.

52 Id. at Sec. 39(1).

53 Id. at Sec. 43: "Notwithstanding anything contained in sub-section (6) of section 23 and section 28, where an essentially derived variety is derived from a farmers' variety, the authorization under subsection (2) of section 28 shall not be given by the breeder of such farmers' variety except with the consent of the farmers or group of farmers or community of farmers who have made contribution in the preservation or development of such variety."

54 Id. 
In this way, the PPVFR Act promotes innovation amongst the traditional farmers, at the same time recognizing and rewarding the contributions made by indigenous farmers, and also protecting biodiversity.

\subsection{Community Rights}

Another extraordinary deviation from the UPOV 1991 Act under the PPVFR Act lies in prescribing a right to community compensation in recognition of traditional knowledge from villages and communities. In this regard, Sec. 43 of the PPVFR Act is a significant departure from Western IP rights philosophy and particularly from the UPOV 1991 Act as this section reflects the community property philosophy by providing that breeders wanting to use farmers'varieties for creating essentially derived varieties cannot do so without the direct permission of the farmers engagement in the conservation of such varieties..$^{55}$ Communities can stake a claim alongside the breeders if a new variety is derived from any lead or contribution made by the local farmers or community. ${ }^{56}$ If the community's claim for compensation is proved, the breeder is obligated to deposit the compensation in the Gene Fund through which the money will be distributed to the actual beneficiaries thereafter. ${ }^{57}$

\subsection{Benefit-Sharing}

The concept of benefit-sharing refers to the idea of sharing a fraction of the benefits accruing to a breeder of a new variety with qualifying claimants who could

55 PPVFRA, Sec. 43.

56 Id. at Sec. 41:"(1) Any person or group of persons (whether actively engaged in farming or not) or any governmental or nongovernmental organization may, on behalf of any village or local community in India, file in any centre notified, with the previous approval of the Central Government, by the Authority, in the Official Gazette, any claim attributable to the contribution of the people of that village or local community, as the case may be, in the evolution or any variety for the purpose of staking a claim on behalf of such village or local community.

(2) Where any claim is made under sub-section (1), the centre notified under that sub-section may verify the claim made by such person or group of persons or such governmental or nongovernmental organization in such manner as it deems fit, and if it is satisfied that such village or local community has contributed significantly to the evolution of the variety which has been registered under this Act, it shall report its findings to the Authority.

(3) When the authority, on a report under sub-section (2) is satisfied, after such inquiry as it may deem fit, that the variety with which the report is related has been registered under the provisions of this Act, it may issue notice in the prescribed manner to the breeder of that variety and after providing opportunity to such breeder to file objection in the prescribed manner and of being heard, it may subject to any limit notified by the Central Government, by order, grant such sum of compensation to be paid to a person or group of persons or governmental or nongovernmental organization which has made claim under sub-section (1), as it may deem fit.

(4) Any compensation granted under sub-section (3) shall be deposited by the breeder of the variety in the Gene Fund.

(5) The compensation granted under sub-section (3) shall be deemed to be an arrear of land revenue and shall be recoverable by the Authority accordingly."

57 Id. 
be indigenous groups, individuals, farmers or communities ${ }^{58}$ The concept of benefitsharing is very close to the community rights concept as elaborated above. The PPVFR Act provides that before registering any new variety, the Plant Authority should call for claims for benefit-sharing..$^{59}$ Farmers or persons or groups can respond based on two criteria:

(a) the extent and/or nature of use of genetic material in the development of the new variety, and

(b) the commercial utility and demand in the market for the new variety. ${ }^{60}$

Only citizens of India or firms or organizations formed or recognized in India are eligible to claim benefits. ${ }^{61}$ However some critics claim that the benefit-sharing

PPVFRA, Sec. 2(b): "... benefit sharing, in relation to a variety, means such proportion of the benefit accruing to a breeder of such variety or such proportion of the benefit accruing to the breeder from an agent or a licensee of such variety, as the case may be, for which a claimant shall be entitled as determined by the Authority under section $26 . "$

59 Id. at Sec. 26:"(1) On receipt of copy of the certificate of registration under sub-section (8) of section 23 or sub-section (2) of section 24, the Authority shall publish such contents of the certificate and invite claims of benefit sharing to the variety registered under such certificate in the manner as may be prescribed.

(2) On invitation of the claims under sub-section (1), any person or group of persons or firm or governmental or nongovernmental organization shall submit its claim of benefit sharing too such variety in the prescribed form within such period, and accompanies with such fees, as may be prescribed:

Provided that such claim shall only be submitted by any -

(i) person or group of persons, if such person or every person constituting such group is a citizen of India; or

(ii) firm or governmental or non-governmental organization, if such firm or organization is formed or established in India.

(3) On receiving a claim under sub-section (2), the Authority shall send a copy of such claim to the breeder of the variety registered under such certificate and the breeder may, on receipt of such copy, submit his opposition to such claim within such period and in such manner as may be prescribed.

(4) The Authority shall, after giving an opportunity of being heard to the parties, dispose of the claim received under sub-section (2).

(5) While disposing of the claim under sub-section (4), the Authority shall explicitly indicate in its order the amount of the benefit sharing, if any, for which the claimant shall be entitled and shall take into consideration the following matters, namely -

(a) the extant [sic] and nature of the use of genetic material of the claimant in the development of the variety relating to which the benefit sharing has been claimed.

(b) the commercial utility and demand in the market of the variety relating to which the benefit sharing has been claimed.

(6) The amount of benefit sharing to a variety determined under this section shall be deposited by the breeder of such variety in the manner referred to in clause (a) of sub-section 45 in the National Gene Fund.

(7) The amount of benefit sharing determined under this section shall, on a reference made by the Authority in the prescribed manner, be recoverable as an arrear of land revenue by the District Magistrate within whose local limits of jurisdiction the breeder liable for such benefit sharing resides."

60 Id.

61 Id. 
provision is disconnected from the farmers, and onerous to implement. ${ }^{62}$ Critics assert that farmers may not be observant in applying for benefits, considering social, economic and other conditions of the local communities. ${ }^{63}$ Subsequently, critics assert that the communities will be left uncompensated for breeders' misappropriations and the actual benefit will not be passed on to the actual claimants.

Further, it has been pointed out by critics that safeguards for local communities are inadequate because the breeder is not required to show prior informed consent by the community or group from which he obtained the traditional knowledge. ${ }^{64}$ Moreover, the lack of regional offices in the local communities could exacerbate the procedural complications for farmers, requiring them to apply to distant offices. ${ }^{65}$ To overcome this problem, it is imperative that NGOs or government bodies be permitted to apply for benefit-sharing on a farmer's behalf.

\subsection{Protection against Innocent Infringement}

Another important protection outlined in Sec. 42 of the PPVFR Act refers to innocent infringement of protected varieties. Innocent infringement, which is a defence against infringement, requires evidence of lack of knowledge or awareness of the protected status of the varieties at the time of infringement. ${ }^{66}$ Such proof can include substances such as the level of literacy of the farmer or the lack of licenses written in his local language. This exception is very important for a country such as India, considering that:

(a) a large number of farmers in India are illiterate, with limited knowledge of their rights and almost negligible knowledge of intellectual property rights mechanisms, and

(b) breeders are generally pitiless in prosecuting infringement, innocent or otherwise, alleged to be done by anyone, and in the case of plant varieties it would be mostly farmers.

The exception is remarkable, with a distinctive national interest. If read together, the right to re-sow and the exemption from accidental infringement provide protection for the farmers' customary way of life and will give them a great sense

62 Sahai 2003, at 409-410.

63 Gopalakrishnan 2001, at 18.

64 Id

65 Id.

66 PPVFRA, Sec. 42: "Notwithstanding anything contained in this Act, -

(i) a right established under this Act shall not be deemed to be infringed by a farmer who at the time of such infringement was not aware of the existence of such right; and

(ii) a relief which a court may grant in any suit for infringement referred to in section 65 shall not be granted by such court, nor any cognizance of any offence under this Act shall be taken, for such infringement by any court against a farmer who proves, before such court, that at the time of the infringement he was not aware of the existence of the right so infringed." 
of certainty to carry out their farming activities without undue fear of infringement cases being filed against them even when they are alleged to be an infringer, as they can claim the defence of innocent infringer.

This provision of the PPVFR Act becomes more significant in the Indian context where the majority of farmers are small and marginal farmers, mostly illiterate and with no knowledge of intellectual property rights. This provision comes to the rescue of all such farmers and also shows the direction to other developing countries that are in the process of formulating their plant varieties protection laws, and that have similar literacy rates and lack of awareness amongst the farming community about intellectual property rights, to overcome such challenges efficiently through including such provisions in their national laws which they have enacted or are going to enact in compliance with the TRIPS Agreement.

\subsection{Compensation in Lieu of Spurious Seed}

To defend farmers from overly optimistic breeders, the PPVFR Act requires breeders to reveal the expected performance. ${ }^{67}$ It provides that if the varieties do not succeed in performing as disclosed by the breeders, then farmers, as consumers, may seek compensation from the breeders. ${ }^{68}$ The Plant Authority shall determine whether the breeder has made spurious claims, and, if so, whether the farmer is entitled to compensation. ${ }^{69}$ The goal is to ensure that quality is not met only halfway in the zeal to market new varieties and that a farmer should not feel embittered after buying seeds from the breeder and after paying him the price as asked by the breeder.

The benefit of the provision is that it forces breeders to adhere to minimum quality specifications and lessens the natural tendencies of big breeders to over publicize. ${ }^{70}$ However, critics have opined that the clause vests limitless discretion in the Plant Authority. ${ }^{71}$ This aspect of unlimited discretion to the Plant Authority can be overcome by limiting the language of the breeders' terms of license, which will presumably demonstrate adequate exceptions.

67 PPVFRA, Sec. 39(2): "Where any propagating material of a variety registered under this Act has been sold to a farmer or a group of farmers of any organization of farmers, the breeder of such variety shall disclose to the farmer or the group of farmers or the organization of farmers, as the case may be, the expected performance under given conditions, and if such propagating material fails to provide such performance under such given conditions, the farmer or the group of farmers or the organization of farmers, as the case may be, may claim compensation in the prescribed manner before the Authority and the Authority, after giving notice to the breeder of the variety and after providing him an opportunity to file opposition in the prescribed manner and after hearing the parties, may direct the breeder of the variety to pay such compensation as it deems fit, to the farmer or the group of farmers or the organization of farmers, as the case may be."

68 Id.

69 Id.

$70 \quad$ Id. at Sec. 39.

71 Sahai 2003, at 410. 


\subsection{Research Exemptions \& Essentially Derived Variety}

The PPVFR Act further encourages research on protected varieties by permitting anyone to use a registered variety for "piloting experiment or research" or as an "initial source of variety for the purpose of creating other varieties." ${ }^{\text {"2 }}$ However, for this purpose, the PPVFR Act requires authorization from the owner of the original variety to derive the second-generation variety. ${ }^{73}$ Such authorization is required only where "repeated use of such variety as a parental line is necessary for commercial production of such newly developed variety." ${ }^{174}$

This provision encourages research while preventing the premature exploitation of protected varieties in the garb of research. In this context, the PPVFR Act takes a stand totally different from that of the UPOV 1991 Act, which vests rights up to two generations of essentially derived varieties in the breeder, and is considered as giving too many rights to the breeders.

Despite the fact that the PPVFR Act defines "essentially derived" similarly to the UPOV 1991 Act, it additionally grants rights over the essentially derived variety (EDV) to the farmer or breeder (second generation breeder) who derived it, and not to the breeder of the initial variety, unless the essentially derived variety was also developed by the breeder of the new variety. ${ }^{75}$ Due to this, it becomes a unique provision of the PPVFR Act. Essentially derived variety can also be registered providing it is supplemented by the required credentials. Critics, however, raise a distressing alarm in this regard stating that the PPVFR Act grants very limited rights to researchers because of the acknowledgement of EDV, which is defined in detail in the UPOV Convention. ${ }^{76}$

According to the extensive definition of EDVs, it is observed that all types of research will become focussed on the breeders' permission if a protected variety is to be used for research. Under the PPVFR Act, the breeders' permission is needed for

72 PPVFRA, Sec. 30: "Nothing contained in this Act shall prevent -

(a) the use of any variety registered under this Act by any person using such variety for conducting experiment or research; or

(b) the use of a variety by any person as an initial source of variety for the purpose of creating other varieties;

Provided that the authorization of the breeder of a registered variety is required where the repeated use of such variety as a parental line is necessary for commercial production of such other newly developed variety."

73 Id. at Sec. 28.

74 Id. at Sec. 30.

75 Id. at Sec. 23(6): "The rights of the breeder of a variety contained in section 28 shall apply to the breeder of essentially derived variety:

Provided that the authorization by the breeder of the initial variety to the breeder of essentially derived variety under subsection (2) of section 28 may be subject to such terms and conditions as both the parties may mutually agree upon."

76 B. Sharma, Paper presented at Workshop on Suitability of UPOV for Developing Countries, Gene Campaign, New Delhi, 10 July 2002. 
making EDVs. The processes for making EDV have been made so all-encompassing in the UPOV 1991 Act - i.e. natural selection, mutant selection, back crosses and transformation by genetic engineering - that all known forms of creating new varieties will be covered. This would restrict the researcher's space to the extent that for almost any kind of research on the protected variety, the permission of the breeders will be needed, establishing their control on a great part of germplasm. ${ }^{77}$ This may very well as a result go against the very objective of the introduction of this provision under the PPVFR Act.

\subsection{Public Interest Exceptions \& Compulsory Licensing}

The public interest exception of the PPVFR Act is much broader than that in the UPOV 1991 Act and shields protection of

public order or public morality or human, animal and plant life and health or to avoid serious prejudice to the environment. ${ }^{78}$

Correspondingly, varieties embodying technology (including inherited and terminator technology), which may be injurious to the public or animals, are condensed non-registrable under the PPVFR Act. ${ }^{79}$ Connected closely with the public interest exception is the all-embracing compulsory license provision. This provision is articulated in Sec. 84 of the Indian Patent Act 1970. It provides that at the end of three years, any protected variety can be subject to compulsory licensing if the

reasonable requirements of the public for seed or other propagating material of the variety have not been satisfied or that the seed or other

77 Sahai 2003.

78 PPVFRA, Sec. 29: "(1) Notwithstanding anything contained in this Act, no registration of a variety shall be made under this Act in cases where prevention of commercial exploitation of such variety is necessary to protect public order or public morality or human, animal and plant life and health or to avoid serious prejudice to the environment.

(2) The Central Government shall, by notification in the Official Gazette, specify the genera or species for the purposes of registration of varieties other than extant varieties and farmers' varieties under this Act.

(3) Notwithstanding anything contained in sub-section (2) and sub-sections (1) and (2) of section 15, no variety of any genera or species which involves any technology which is injurious to the life or health of human beings, animals or plants shall be registered under this Act.

Explanation: For the purposes of this sub-section, the expression 'any technology' includes genetic use restriction technology and terminator technology.

(4) The Central Government shall not delete any genera or species from the list of genera or species specified in a notification issued under sub-section (2) except in the public interest.

(5) Any variety belonging to the genera or species excluded under sub-section (4) shall not be eligible for any protection under this Act."

79 Id. 
propagating material of the variety is not available to the public at a reasonable price. $^{80}$

Price shall also be a consideration in determining whether the practical requirements of the public are satisfied. The purpose of this is to use compulsory licensing as a deterrent in order to keep prices of protected varieties low-slung. While granting such compulsory licenses to safeguard the interests of the commercial breeders, the PPVFR Act provides for reasonable compensation to the breeder of the variety relating to the compulsory license having regard to the nature of the variety, the outlay sustained by such breeder in breeding the protected variety or for developing it, and other pertinent aspects. ${ }^{81}$

\subsection{National Gene Fund for Promoting PGR Activities}

India is a country of rich biodiversity and plant genetic resources. On the basis of the richness of its agro-biodiversity - i.e. the number of crop classes, crop varieties, wild relatives of various crop species cultivated, social significance, wild varieties of crop species occurring in the region, and the number of classes tamed and the uniqueness of the agro-ecosystems - the Plant Authority has identified 22 agrobiodiversity hotspot regions in India as per the above picture.

Farmers who have been involved in conservation and preservation of plant genetic resources (PGR) of land races and wild relatives of commercial plants and their improvement through selection and preservation in these identified 22 agrobiodiversity hotspots receive recognition and rewards through the National Gene Fund. This provision, when taken in combination with the provisions relating to the farmers' privilege, is similar to the concept of Farmers' Rights contained in the ITPGRFA, which prescribes such provisions while recognizing farmers' rights.

${ }^{80}$ PPVFRA, Sec. 47:"(1) At any time, after the expiry of three years from the date of issue of a certificate of registration of a variety, any person interested may make an application to the Authority alleging that the reasonable requirements of the public for seed or other propagating material of the variety have not been satisfied or that the seed or other propagating material of the variety is not available to the public at a reasonable price and pray for the grant of a compulsory license to undertake production, distribution and sale of the seed or other propagating material of that variety.

(2) Every application under sub-section (1) shall contain a statement of the nature of the applicant's interest together with such particulars as may be prescribed and the facts upon which the application is based.

(3) The Authority, after consultation with the Central Government, and if satisfied after giving an opportunity to the breeder of such variety to file opposition and after hearing the parties, on the issue that the reasonable requirements of the public with respect to the variety have not been satisfied or that the seed or other propagating material of the variety is not available to the public at a reasonable price, may order such breeder to grant a license to the applicant upon such terms and conditions as it may deem fit and send a copy of such order to the Registrar to register the title of such applicant as licensee under sub-section (4) of section 28 on payment of such fees by the applicant as is referred to in that sub-section."

${ }^{81}$ Id. at Sec. 51(1)(i). 


\subsection{Exemption to Farmers from Fees}

In order to promote the filing of applications of farmers' variety and for other processes, the PPVFR Act exempts a farmer or group of farmers or village community from paying any fees in any proceeding before the Authority or Registrar or the Tribunal or the High Court under this Act or the rules made thereunder. ${ }^{82}$

While the PPVFR Act is not free from flaws, the Act showcases that farmers' and breeders' rights can be adequately and concurrently protected under a single piece of legislation so as to take care of the interests of both the stakeholders. ${ }^{83}$ In a country like India, ensuring food security by providing farmers' rights is important for economic steadiness. ${ }^{84}$ The PPVFR Act's effectiveness lies in catering to the requirements of the nations that desires to promote innovation and technological advancement without intimidating farmers' livelihood. ${ }^{85}$

The TRIPS Agreement grants members the flexibility to rank farmers in shaping a policy for plant variety protection. The PPVFR Act is adept in its ability to exploit the flexibilities in the TRIPS Agreement. India should now work on eliminating the ambiguities in the PPVFR Act.

\section{Trends of Application under the PPVFR Act}

An analysis of the plant variety application trends from the period 2007 to 2014 aims at finding out the effectiveness of the PPVFR Act. As on 31 December 2014, the PPVFR Authority received 1,364 applications from the public sector, 2,751 applications from the private sector and 4,349 applications from farmers.

Table 2: Applications Filed Year-Wise under the PPVFR Act ${ }^{86}$

\begin{tabular}{|c|c|c|c|c|c|c|c|c|c|}
\hline Sector & $\mathbf{2 0 0 7}$ & $\mathbf{2 0 0 8}$ & $\mathbf{2 0 0 9}$ & $\mathbf{2 0 1 0}$ & $\mathbf{2 0 1 1}$ & $\mathbf{2 0 1 2}$ & $\mathbf{2 0 1 3}$ & $\mathbf{2 0 1 4}$ & Total \\
\hline Public & 287 & 322 & 193 & 31 & 125 & 129 & 141 & 136 & $\mathbf{1 3 6 4}$ \\
\hline Private & 143 & 220 & 368 & 505 & 295 & 266 & 534 & 420 & $\mathbf{2 7 5 1}$ \\
\hline Farmers & 2 & 5 & 127 & 4 & 941 & 304 & 1002 & 1964 & $\mathbf{4 3 4 9}$ \\
\hline Total & $\mathbf{4 3 2}$ & $\mathbf{5 4 7}$ & $\mathbf{6 8 8}$ & $\mathbf{5 4 0}$ & $\mathbf{1 3 6 1}$ & $\mathbf{6 9 9}$ & $\mathbf{1 6 7 7}$ & $\mathbf{2 5 2 0}$ & $\mathbf{8 4 6 4}$ \\
\hline
\end{tabular}

82 PPVFRA, Sec. 44: "A farmer or group of farmers or village community shall not be liable to pay any fees in any proceeding before the Authority or Registrar or the Tribunal or the High Court under this Act or the rules made thereunder."

83 Gopalakrishnan 2001, at 3.

84 Sahai 2003.

85 Id.

${ }^{86}$ Available at http://www.plantauthority.gov.in. 
The performance of public sector institutions in filing applications for PVP was encouraging in the beginning, as a good number of applications were received between 2007 and 2009. However, from 2010 to 2012 the filing slowed down. In comparison to the private sector, except for filing applications under the extant variety category, the performance was not encouraging. Public institutions, as a social commitment, submitted more applications in "high volume and low value crops" such as self-pollinated crops.

The performance of the private sector in filing applications for PVP is encouraging from the beginning of the registration of plant varieties in comparison to the public seed industry. Private seed companies showed more interest in filing their plant variety applications, particularly in "high value, low volume crops" such as cotton, maize, sorghum, bajra, rice, vegetables, etc.; as a result, a record number of 2,751 applications were filed in comparison to the public institutions, which filed only 1,364 applications, indicating that the Indian legislation is a balanced Act, and is friendly is both the public and the private seed industry.

Table 3: Registration Certificates Issued Year-Wise under the PPVFR Act ${ }^{87}$

\begin{tabular}{|c|c|c|c|c|c|c|c|c|c|}
\hline Sector & $\mathbf{2 0 0 7}$ & $\mathbf{2 0 0 8}$ & $\mathbf{2 0 0 9}$ & $\mathbf{2 0 1 0}$ & $\mathbf{2 0 1 1}$ & $\mathbf{2 0 1 2}$ & $\mathbf{2 0 1 3}$ & $\mathbf{2 0 1 4}$ & Total \\
\hline Public & - & - & 149 & 49 & 95 & 154 & 154 & 250 & $\mathbf{8 5 1}$ \\
\hline Private & - & - & 16 & - & 21 & 55 & 104 & 124 & $\mathbf{3 2 0}$ \\
\hline Farmers & - & - & 3 & - & - & 3 & 46 & 459 & $\mathbf{5 1 1}$ \\
\hline Total & - & - & $\mathbf{1 6 8}$ & $\mathbf{4 9}$ & $\mathbf{1 1 6}$ & $\mathbf{2 1 2}$ & $\mathbf{3 0 4}$ & $\mathbf{8 3 3}$ & $\mathbf{1 , 6 8 2}$ \\
\hline
\end{tabular}

With regard to the issue of PVP certificates, more certificates (851) were issued to the public seed industry in comparison to the private seed companies (320). This is mainly because the certificates issued to the public institutions are mostly Extant Varieties Notified under the Seeds Act 1966, while private institutions mostly submitted their applications under the New Variety, VCK and EDV categories, which require testing for DUS and additional time.

\section{Conclusion}

The PPVFR Act showcases that farmers' and breeders' rights can be adequately and concurrently protected under a single piece of legislation so as to take care of the interests of both the stakeholders and despite its significant difference from the UPOV model which primarily focuses on breeders' rights. In a country such as India, ensuring food security by providing farmers' rights is important for economic stability. The

\footnotetext{
${ }^{87}$ Available at http://www.plantauthority.gov.in.
} 
PPVFR Act's effectiveness lies in catering to the needs of nations that wish to promote innovation and technological advancement without threatening farmers' livelihoods.

The PPVFR Act is exemplary in its ability to capitalize on the flexibilities in the TRIPS Agreement. India should now work on eliminating a few of the loopholes in the PPVFR Act. Strengthening the theoretical framework of the Act can result in a resourceful sui generis model for plant varieties as well as farmers' rights protection tailored towards objectives of promoting innovation and cutting-edge research, on the one hand, and recognizing and safeguarding the contributions and rights of farmers, on the other, which has also become a model legislation for many developing countries. For that purpose, there is an urgent need for the harmonization of parallel laws including the Biological Diversity Act, the Seeds Bill and the PPVFR Act in order to better serve the purpose without overlapping.

\section{References}

Antons C. Sui Generis Protection for Plant Varieties and Traditional Knowledge in Biodiversity and Agriculture: The International Framework and National Approaches in the Philippines and India, 6 Indian Journal of Law and Technology 89 (2010).

Heald P.J. Mowing the Playing Field: Addressing Information Distortion and Asymmetry in the TRIPS Game, 88 Minnesota Law Review 249 (2003).

Long D.E. The Impact of Foreign Investment on Indigenous Culture: An Intellectual Property Perspective, 23 North Carolina Journal of International Law and Commercial Regulation 229 (1998).

Ragavan S. \&. Mayer J. Has India Addressed Its Farmers' Woes? A Story of Plant Protection Issues, 20 Georgetown Environmental Law Review 97 (2007).

Ranjan P. Recent Developments in India's Plant Variety Protection, Seed Regulation and Linkages with UPOV's Proposed Membership, 12(3) Journal of World Intellectual Property 219 (2009).

Straus J. Bargaining Around the TRIPS Agreement: The Case for Ongoing PublicPrivate Initiatives to Facilitate Worldwide Intellectual Property Transactions, 9 Duke Journal of Comparative \& International Law 91 (1998).

\section{Information about the authors}

Rohit Moonka (Ahmedabad, India) - Assistant Professor of Law, Head of the Centre for ADR, Institute of Law, Nirma University (SG Highway, Ahmedabad, Gujarat, 382481, India; e-mail: rohitmoonka@gmail.com).

Silky Mukherjee (Ahmedabad, India) - Assistant Professor of Law, Institute of Law, Nirma University (SG Highway, Ahmedabad, Gujarat, 382481, India; e-mail: silkym.08@gmail.com). 